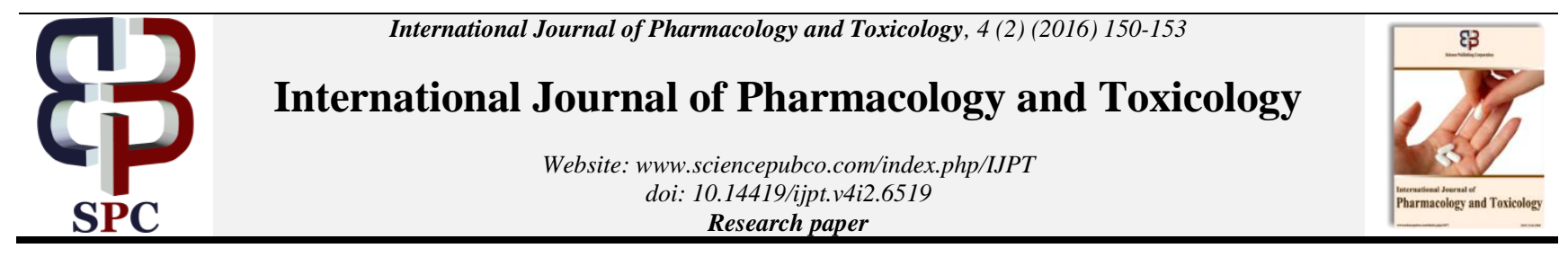

\title{
Effect of three anticoccidials on pharmacokinetics of tilmicosin in broiler chickens
}

\author{
Mohamed El-Hewaity * \\ Department of Pharmacology, Faculty of Veterinary Medicine, University of Sadat City, Egypt \\ *Corresponding author E-mail:melhewaty@yahoo.com
}

\begin{abstract}
The disposition kinetic of tilmicosin $(25 \mathrm{mg} / \mathrm{kg})$ was studied following oral administration alone, pretreated with amprolium (240 ppm), pretreated with diclazuril $(2.5 \mathrm{ppm})$ and pretreated with toltrazuril $(25 \mathrm{ppm})$ in broiler chickens. The serum tilmicosin concentrations were determined by microbiological assay technique using Bacillus subtilis (ATCC 6633) as the test organism. Following oral administration of tilmicosin, the disposition curve was best described by two-compartment open model. The maximum serum concentration $\left(\mathrm{C}_{\max }\right)$ was $1.90 \pm 0.11,1.27 \pm 0.13,1.50 \pm 0.14$ and $1.41 \pm 0.11 \mu \mathrm{g} / \mathrm{ml}$ for tilmicosin alone and in the presence of amprolium, diclazuril and toltrazuril, respectively. The elimination half-life $\left(\mathrm{T}_{0.5 \text { (ell })}\right)$ was significantly decreased $(5.28 \pm 0.30,5.88 \pm 0.33,6.03 \pm 0.25 \mathrm{~h}$, respectively) in amprolium, diclazuril and toltrazuril pretreated broiler chicken compared to tilmicosin alone ( $7.30 \pm 0.41 \mathrm{~h})$. The outcomes illustrated a significant decrease in the interval between doses in amprolium, diclazuril and toltrazuril pretreated broiler chicken compared to tilmicosin alone. Amprolium diclazuril and toltrazuril, resulted in a significance decrease in AUC $(12.02 \pm 1.14,15.50 \pm 1.26$ and $14.56 \pm 1.46 \mu \mathrm{g} . \mathrm{h} . \mathrm{ml}^{-1}$, respectively) compared to tilmicosin alone $\left(21.98 \pm 1.83 \mu \mathrm{g} . \mathrm{h} . \mathrm{ml}^{-1}\right)$. It is concluded that the administration of amprolium, diclazuril and toltrazuril before tilmicosin would altered its pharmacokinetic profile in broiler chicken.
\end{abstract}

Keywords: Anticoccidials, Broiler Chickens, Kinetic, Tilmicosin

\section{Introduction}

The attendant utilization of more than one drug is possible in the field of veterinary prescription exceptionally the poultry farm, for example the accompanying utilizing of anticoccidial, antibiotics, and growth promoters, at the same time to overcome diseases (Jones and Ricke 2003). The accompanying utilization of various medications with each other may result in drug-drug interactions. Drug-drug interactions may prompt changes in the concentrations of drug in the body, which may exaggerate or impair the proposed viability of the antibiotics utilized for treatment of bacterial diseases.

The macrolide is a group of compounds which comparable in the structure, the vast majority of which are gotten from numerous types of Streptomyces soil-borne bacteria (Scott et al. 1996). Macrolides are effective against Gram-positive bacteria, such as Streptococcus spp. what's more, Staphylococcus spp., Mycoplasma spp, however are marginally successful against Gram-negative living beings (Botsolou and Fletouris 2001). Tilmicosin is a bacteriostatic macrolide antibiotic got from tylosin for veterinary use only. It is predominantly viable against Mycoplasma spp., Pasteurella spp., and many Gram-positive bacteria with viability against anaerobic bacteria and some Gram-negative respiratory bacteria such as Pasteurella multocida and Mannheimia haemolytica (Prescott 2000). In poultry farm, tilmicosin utilized for respiratory tract contaminations treatment which caused by Mycoplasma synoviae, Mycoplasma gallisepticum, Pasteurella multocida and Ornithobacterium rhinotracheale (Kempf et al. 1997; Abu-Basha et al. 2007). Amprolium is a thiamine analogue, which is broadly utilized as a part of coccidiosis in poultry and rabbit's farms (McDougald and Reid 1997). It may interact with any administered drugs, as it is normally added as a food added substance to poultry rations. Toltrazuril is a triazinetrione derivative. It is expected for the avoidance and treatment of coccidiosis in chickens and turkeys (Vertommen et al. 1990). Diclazuril chemically, 2-(4Chlorophenyl)-2- [2, 6-dichloro-4-(3, 5-dioxo-1, 2, 4-triazin-2-yl) phenyl] acetonitrile, is a potent anticoccidial drug. The utilizing of diclazuril is broadly as a part of most animal varieties including chickens, turkeys, cattle, and pigs for treatment and counteractive action of coccidiosis (Taylor et al. 2003).

The point of this study is to examine the impact of amprolium, diclazuril and toltrazuril pretreatment on the pharmacokinetics of tilmicosin following a single oral administration in broiler chickens.

\section{Materials and methods}

\subsection{Drug}

Tilmicosin was obtained as an oral solution under trade name (Tilmosol 25\%) ${ }^{\circledR}$ from Arab Company for Medical Products (ARABCOMED). Each $100 \mathrm{ml}$ contains tilmicosin phosphate 28 gm equivalent to tilmicosin base $25 \mathrm{gm}$.

Amprolium was obtained as water soluble powder under trade name (Amprolium 20\%) ${ }^{\circledR}$ from Adwia company.

Diclazuril was obtained as oral solution under trade name (Diclosol) ${ }^{\circledR}$ from Pharma-Swede Egypt company.

Toltrazuril was obtained as oral solution under trade name (Prima$\operatorname{cox} 2.5 \%$ ) ${ }^{\circledR}$ from Primavet company. 


\subsection{Birds}

Twenty-four clearly solid Hubbard broiler chickens of both genders weighing from 1100-1450 $\mathrm{g}$ were utilized as a part of this examination. Chickens were acquired from a private poultry farm, then housed in hygienic floor system and were sustained on adjusted antimicrobial free ration. Water was offered not obligatory. Prior to the begin of investigations, chickens were watched for 2 weeks to ensure that their bodies are free from any anti-bacterial substances. The investigation was performed as per the rules set by the Ethical Committee of El-Sadat city University, Egypt.

\subsection{Experimental design}

Four principle groups of 6 chickens each were utilized. Birds of the $1^{\text {st }}$ group were left as control group while those in the $2^{\text {nd }}, 3^{\text {rd }}$ and $4^{\text {th }}$ groups were pretreated with amprolium $(240 \mathrm{ppm})$ for 5 consecutive days, diclazuril (2.5 ppm) for 2 consecutive days and toltrazuril $(25 \mathrm{ppm})$ for 2 consecutive days, respectively. After the last dose by 2 hours (to ensure that amprolium, diclazuril and toltrazuril reach its maximum serum concentration), each chicken in all groups was orally administered $25 \mathrm{mg} / \mathrm{kg}$ BW of tilmicosin Blood samples were collected from the right wing vein of each bird at 10, 20 and 30 minutes and 1, 2, 4, 6, 8, 12 and 24 hours All blood samples were collected in sterilized centrifuged tubes and allowed to clot. Serum was separated by centrifugation at 3000 r.p.m for 10 minutes. Sera were kept frozen until assayed.

\subsection{Drug bioassay}

Tilmicosin in blood samples was assayed using microbiological method of antibiotic using Bacillus subtilis (ATCC 6633) as a test organism (Arret et al. 1971). Standard curves were constructed using antibacterial free serum collected from chicken and phosphate buffer. Six wells, $8 \mathrm{mmin}$ diameter, were cut at equal distances in standard Petri dishes containing $25 \mathrm{~mL}$ seeded agar. The wells were filled with $100 \mu \mathrm{L}$ of either the test samples tilmicosin standards. The plates were kept at room temperature for $2 \mathrm{~h}$ before being incubated at $37^{\circ} \mathrm{C}$ for $18 \mathrm{~h}$. Zones of inhibition were measured using micrometers, and tilmicosin concentrations in the test samples were calculated from the standard curve.

The standard curve in chicken serum was linear over the range of 0.097 to $25 \mu \mathrm{g} / \mathrm{ml}$ and the value of correlation coefficient (r) was
0.78. The limit of quantification was $0.097 \mu \mathrm{g} / \mathrm{ml}$. Protein binding of tilmicosin was estimated according to (Craig and Suh 1991). This method was based on the diffusion of free antibiotic into the agar medium. To estimate the protein binding of tilmicosin, the drug was dissolved in phosphate buffer and antibiotic free chicken's serum at different concentrations. This estimation was based on the facts that free unbound part of tilmicosin only capable to diffuse through agar. The differences in the diameters of the inhibition zones between the solutions of the drug in the phosphate buffer and serum samples were then calculated according to the following equation:

Protein binding $\%=$

Zone of inhibition in buffer - Zone of inhibition in serum / Zone of inhibition in buffer $\mathrm{x} 100$

\subsection{Pharmacokinetic analysis}

Serum concentrations of tilmicosin for each individual chicken after oral administrations were subjected to a compartmental investigation utilizing a nonlinear least-squares regression analysis with the assistance of a computerized curve-stripping program ( $R$ Strip; Micromath Scientific Software, Salt Lake City, UT, USA). For PO data, the appropriate pharmacokinetic model was controlled by visual examination of individual concentration-time curves and by application of Akaike's Information Criterion (AIC) Yamaoka et al. 1978. The pharmacokinetic parameters were reported as mean \pm SD. Information acquired all through the study were investigated utilizing Students t-test (Snedecor and Cochran 1976).

\section{Results}

In the present study, all chickens were clearly sound amid the time of investigation and all medications were well tolerated. The serum tilmicosin concentrations following its oral administration alone, pretreated with amprolium, pretreated with diclazuril and pretreated with toltrazuril ware incorporated in figure (1). The semi logarithmic serum concentration-time curve of tilmicosin in broilers, after oral administration of $25 \mathrm{mg} / \mathrm{kg}$ b.wt showed that the drug complied with a two-compartment open model.
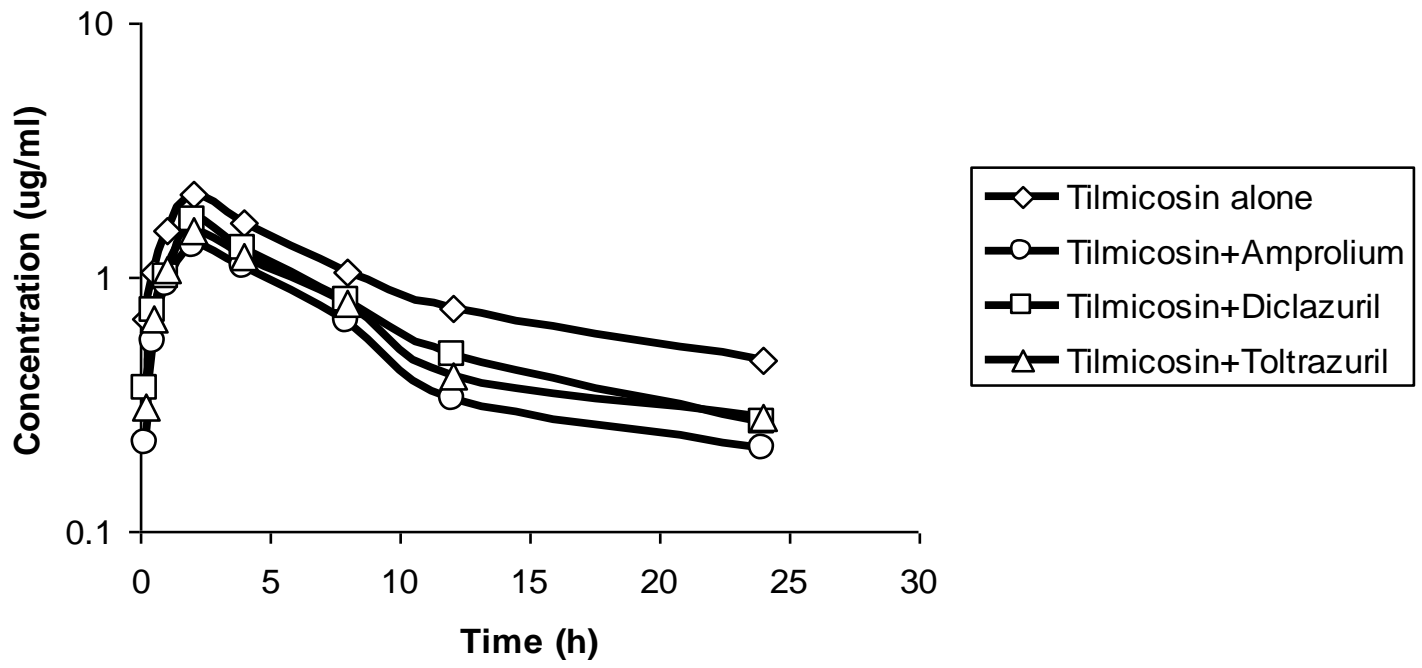

Fig. 1: Semi-Logarithmic Graph Depicting the Time Course of Tilmicosin In Broilers after A Single Oral Administration of 25 Mg/Kg.B.Wt. Alone, Pretreated with Amprolium Orally at A Dose Rate of 240 Ppm, Pretreated with Diclaazuril Orally at A Dose Rate Of 2.5ppm and Pretreated with Toltrazuril Orally at A Dose Rate of $25 \mathrm{ppm}$. $(\mathrm{N}=6)$.

Tilmicosin was firstly identified in serum 15 minutes following its oral administration. The mean top serum level $(1.90 \pm 0.11 \mu \mathrm{g} / \mathrm{ml})$ was accomplished at time $\left(\mathrm{T}_{\max }\right) 2.13 \pm 0.19 \mathrm{~h}$ post administration. The tilmicosin was still identified above MIC up to $24 \mathrm{~h}$ after administration alone or pretreated with amprolium, diclazuril and toltrazuril. No tilmicosin could be detected thereafter. The acquired information revealed that the serum tilmicosin concentrations was decreased significantly at various time intervals in amprolium, diclazuril and toltrazuril pretreated broiler chickens compared to values recorded in tilmicosin alone. 
The pharmacokinetic parameters of tilmicosin taking after its oral administration alone, pretreated with amprolium, pretreated with diclazuril and pretreated with toltrazuril were recorded in table (1). The acquired results demonstrated that the in vitro protein binding tendency of tilmicosin to broiler chicken serum protein was 14.79 $\pm 1.18 \%$. This finding showed that the drug is somewhat bound to serum protein.

Table 1: Mean pharmacokinetic parameters of tilmicosin in broilers after a single oral administration of $25 \mathrm{mg} / \mathrm{kg} . \mathrm{b} . \mathrm{wt}$. Alone, pretreated with amprolium orally at a dose rate of $240 \mathrm{ppm}$, pretreated with diclaazuril orally at a dose rate of $2.5 \mathrm{ppm}$ and pretreated with toltrazuril orally at a dose rate of $25 \mathrm{ppm}$. (n=6).

\begin{tabular}{|c|c|c|c|c|c|}
\hline PARAMETER & UNIT & TIMICOSIN ALONE & $\begin{array}{l}\text { TIMICOSIN + } \\
\text { AMPROLIUM }\end{array}$ & $\begin{array}{l}\text { TIMICOSIN + DI- } \\
\text { CLAZURIL }\end{array}$ & $\begin{array}{l}\text { TIMICOSIN + } \\
\text { TOLTRAZURIL }\end{array}$ \\
\hline $\mathrm{K}_{\mathrm{ab}}$ & $\mathrm{h}^{-1}$ & $1.35 \pm 0.11$ & $1.11 \pm 0.12$ & $1.12 \pm 0.14$ & $1.25 \pm 0.09$ \\
\hline $\mathrm{T}_{0.5}(\mathrm{ab})$ & $\mathrm{h}$ & $0.51 \pm 0.07$ & $0.62 \pm 0.05$ & $0.61 \pm 0.06$ & $0.55 \pm 0.06$ \\
\hline $\mathrm{K}_{\mathrm{el}}$ & $\mathrm{h}^{-1}$ & $0.095 \pm 0.01$ & $0.13 \pm 0.02$ & $0.12 \pm 0.02$ & $0.11 \pm 0.01$ \\
\hline $\mathrm{T}_{0.5(\mathrm{el})}$ & $\mathrm{h}$ & $7.30 \pm 0.41$ & $5.28 \pm 0.30 * *$ & $5.88 \pm 0.33 *$ & $6.03 \pm 0.25 *$ \\
\hline $\mathrm{C}_{\max }$ & $\mu \mathrm{g} \cdot \mathrm{ml}^{-1}$ & $1.90 \pm 0.11$ & $1.27 \pm 0.13 * *$ & $1.50 \pm 0.14 *$ & $1.41 \pm 0.11 *$ \\
\hline $\mathrm{T}_{\max }$ & $\mathrm{h}$ & $2.13 \pm 0.19$ & $2.30 \pm 0.23$ & $2.33 \pm 0.25$ & $2.20 \pm 0.15$ \\
\hline AUC & $\mu \mathrm{g} \cdot \mathrm{h} \cdot \mathrm{ml}^{-1}$ & $21.98 \pm 1.83$ & $12.02 \pm 1.14 * * *$ & $15.50 \pm 1.26^{*}$ & $14.56 \pm 1.46^{* *}$ \\
\hline MRT & $\mathrm{h}$ & $8.39 \pm 0.78$ & $7.32 \pm 0.51$ & $7.73 \pm 0.62$ & $7.75 \pm 0.43$ \\
\hline IBD & $\mathrm{h}$ & $28.01 \pm 3.23$ & $19.48 \pm 1.67 *$ & $20.36 \pm 3.54$ & $21.19 \pm 2.61$ \\
\hline
\end{tabular}

$\mathrm{P}<0.05 * * \mathrm{P}<0.01 * * * \mathrm{P}<0.001$

$\mathrm{K}_{\mathrm{ab}}$ : First-order absorption rate constant; $\mathrm{T}_{0.5(\mathrm{ab})}$ : Absorption half-life; $\mathrm{K}_{\mathrm{el}}$ : First-order elimination rate constant; $\mathrm{T}_{0.5(\mathrm{el})}$ : Elimination half-life; $\mathrm{C}_{\mathrm{max}}$ : Maximum serum concentration; $\mathrm{T}_{\max }$ : Time to peak serum concentration; $\mathrm{AUC}_{(0 \text {-inf })}$ : Area under serum concentration-time curve; MRT: Mean residence time; IBD: Interval between doses

\section{Discussion}

After intravenous administration of tilmicosin in broiler chicken, cardiovascular toxicity and deaths have been mentioned by (Main et al. 1996; Papich and Riviere 2001). For this reason, I cannot calculate the bioavailability of tilmicosin in my study.

Following oral administration of tilmicosin in broiler chicken $(25$ $\mathrm{mg} / \mathrm{kg}$ ), the outcomes demonstrated that serum tilmicosin fixation versus time complied with a two-compartments open model which show the presence of two stages (circulation and disposal) stages. This outcome is like the outcome recorded for tilmicosin in swine (Shen et al. 2005). The maximum serum concentration of tilmicosin after oral administration was $1.90 \pm 0.11 \mu \mathrm{g} / \mathrm{ml}$. This finding was coordinating with that recorded for tilmicosin in chicken $2.09 \pm 0.37 \mu \mathrm{g} / \mathrm{ml}$ (Abu-Basha et al. 2007), while this quality was higher than reported in swine $1.19 \pm 0.30 \mu \mathrm{g} / \mathrm{ml}$ (Shen et al. 2005). On the other hand, time to peak serum concentration was $2.13 \pm 0.19 \mathrm{~h}$. This outcome was near that recorded for tylosin in chicken2.36 $\pm 0.42 \mathrm{~h}$ (Abu-Basha et al. 2012). While it was shorter than the result recorded for tilmicosin in chicken $3.99 \pm$ $0.84 \mathrm{~h}$ (Abu-Basha et al. 2007). In this study, the calculated AUC (0-24) was observed to be $21.98 \pm 1.83 \mu \mathrm{g} \cdot \mathrm{h} \cdot \mathrm{ml}^{-1}$. The got result is like that recorded for tilmicosin in chicken $21.82 \pm 3.14 \mu \mathrm{g} . \mathrm{h} . \mathrm{ml}^{-1}$ (Abu-Basha et al. 2007) and for tylosin in broiler chicken $18.60 \pm$ $1.50 \mu$ g.h.ml ${ }^{-1}$ (Soliman and Sedek 2016). In any case, the Area under serum concentration-time curve reported in this study is higher than rates reported in pig $9.68 \pm 0.91 \mu \mathrm{g} . \mathrm{h} . \mathrm{ml}^{-1}$ (Dimitrova et al. 2011). Such contrasts are regular and habitually identified with interspecies variety, examine strategies utilized, age, breed and wellbeing status of the creature, and the plan of the medication utilized (Haddad et al. 1985).

The elimination half-life $\left(\mathrm{t}_{0.5 \mathrm{el}}\right)$ was $7.30 \pm 0.41 \mathrm{~h}$. These outcomes are reliable with those recorded for tylosin in broiler chickens (Soliman and Sedek 2016). However, it was longer than the outcome recorded for tylosin in chickens (Abu-Basha et al. 2012). These varieties may be credited to species contrasts, solid status and the measurement controlled for every situation.

One of the points of this study was to figure out whether there is a pharmacokinetic connection amongst tilmicosin and three anticoccidial in broiler chickens. Taking after oral administration, the mean serum concentrations of tilmicosin were significantly lower in amprolium, diclazuril and toltrazuril pretreated broiler chicken contrasted with tilmicosin alone. Comparative discoveries were already reported for amprolium and toltrazuril with levofloxacin in broilers (El-Banna et al. 2013). Additionally, this outcome was in concurring with that recorded for amprolium with amoxicillin in broiler chicken and for amprolium with lincomycin in broiler chicken (El-Sayed et al. 2014 and El-Sayed et al. 2015), respectively.

The significance diminishes in $\mathrm{C}_{\max }$ of tilmicosin when pretreated with amprolium, diclazuril or toltrazuril in broilers could be clarified on the premise of the impact of amprolium, diclazuril and toltrazuril on microsomal catalysts of liver. In this appreciation, comparative perception was beforehand reported by Abo ElSooud (2003) on co-administration of enrofloxacin with albendazole in goats. Both albendazole and toltrazuril are profoundly metabolized to sulphone in liver (Brander et al. 1991), a phenomenon which could clarify the plausible comparability of both medications in impelling CYP 450 catalysts in creatures and flying creatures and hence the quick digestion system and lower $\mathrm{C}_{\max }$ of tilmicosin. Pretreatment of chickens with toltrazuril two days before tilmicosin administration is sufficient time to prompt liver microsomal CYP 450 proteins, in spite of the fact that Abo ElSooud (2003) found that a single dose of albendazole was adequate to affect such induction in goats. Moreover, this result was in agreeing with that recorded by (Atef et al. 2010) who found that goats pre-treated with rafoxanide or albendazole demonstrated a significant decline in serum florfenicol level when contrasted with non-anthelmintic treated goats.

Amprolium, diclazuril and toltrazuril brought about a significance diminish in the elimination half-life and the area under serum concentration-time curve contrasted with tilmicosin alone. Comparative discoveries were already reported for amprolium and toltrazuril with levofloxacin in broilers (El-Banna et al. 2013). This result was in agreeing with that recorded for diclazuril with tylosin in broiler chicken (Atef et al. 2009). The interval between doses demonstrated lower values in amprolium, diclazuril and toltrazuril pretreated broiler chicken appeared differently in relation to tilmicosin alone. Similar disclosures were at that point reported for amprolium and toltrazuril with levofloxacin in broilers (El-Banna et al. 2013).

\section{Conclusion}

It is reasoned that administration of amprolium, diclazuril and toltrazuril before tilmicosin in broiler chickens would altered its kinetic profiles of oral tilmicosin. Therefore, under this condition, the dose of tilmicosin administration by oral route needs to be deliberately balanced. 


\section{Conflict of interests}

The author declares that there is no conflict of interests regarding the publication of this article.

\section{References}

[1] Abou El-Sooud, K. 2003, Influence of albendazole on the disposition kinetics and milk antimicrobial equivalent activity of enrofloxacin in lactating goats. Pharmacology Research, 48, 389-395. http://dx.doi.org/10.1016/S1043-6618(03)00179-8.

[2] Abu-Basha, E.A., Al-Shunnaq, A.F. and Gehring, R. 2012, Comparative pharmacokinetics and bioavailability of two tylosin formulations in chickens after oral administration. J HELLENIC VET MED SOC, 63, 159-166.

[3] Abu-Basha, E. A., Idkaidek, N. M. and Al-Shunnaq, A. F. 2007, Pharmacokinetics of tilmicosin (Provitil powder and pulmotil liquid AC) oral formulations in chickens. Veterinary Research Communi cations, 31, 477-485. http://dx.doi.org/10.1007/s11259-006-35436.

[4] Arret, B., Johnson, D. and Kirshboum, A. 1971, Outline of details for microbiological assay of antibiotics, second revision. Pharma$\begin{array}{lll}\text { cology } & \text { Science, } & 60,\end{array}$ http://dx.doi.org/10.1002/jps.2600601122.

[5] Atef, M., El-Gendi, A.Y., Aziza, M.M., Abd El-Aty, A.M. 2010 Effect of three anthelmentics on disposition kinetic of florfenicol in goats. Food and Chemical Toxicology, 48, 3340-3344 http://dx.doi.org/10.1016/i.fct.2010.08.039.

[6] Atef, M., El-Gendi, A.Y., Aziza, M.M., Kamel, G. 2009, Pharmacokinetic Assessment of Tylosin Concomitantly Administered with Two Anticoccidials Diclazuril and Halofuginone in Broiler Chickens. Advances in Environmental Biology, 3, 210-218.

[7] Botsolou, N. A. and Fletouris, D. J. 2001, "Drug residues in foods," in Antimicrobial Growth Promoters, pp. 189-190, Marcel Dekker, New York, NY, USA.

[8] Brander, G.C., Pugh, D.M., Baywater, R.J. and Jenkins, W.L. 1991 Veterinary Applied Pharmacology and Therapeutics. Fifth Ed. The English language Book Society and Boilliere, Trindall, London.

[9] Craig, A.W. and Suh, B. 1980, Protein binding and the antibacterial effects. Method for the determination of protein binding, in: LORIAN, V. (Ed.) Antibiotics in Laboratory Medicine, $3^{\text {rd }}$ edn, (Baltimore, Maryland, USA, Williams \& Wilkins) pp. 367-402.

[10] Dimitrova, D., Katsarov, V., Dimitrov, D. and Tsoneva, D. 2011 , Pharmacokinetics of tilmicosin after oral application of Pulmotil G 200 - premix in pigs. AGRICULTURAL SCIENCE AND TECHNOLOGY, 3, $318-322$.

[11] El-Banna, H. A., El- Hewaity, M.H. and Amera Abd El Latif 2013, Influence of amprolium and toltrazuril on the disposition kinetics of levofloxacin in broiler chickens. Egyptian.Acadamic Journal of Biology Science, 5, 1-10.

[12] El-Sayed, M.G., El-Komy, A., El-barawy, A.M. and Gehan, M.E.A 2014, Pharmacokinetical Interactions of Amoxicillin and Amprolium in Broiler Chickens. Physiology and Pharmacology Advances, 4, 515-524. http://dx.doi.org/10.5455/jppa.20141208013007.

[13] El-Sayed, M.G., El-Komy, A., El-barawy, A.M. and Gehan, M.E.A 2015, PHARMACOKINETICAL INTERACTIONS OF LINCOMYCIN AND AMPROLIUM IN BROILER CHICKENS Journal of Science, 5, 734-743.

[14] Haddad, N. S., Pedersoli, W. M., Ravis, W. R., Fazel,M. H. and Carson, R. L. 1985, "Pharmacokinetics of gentamicin at steadystate in ponies: serum, urine, and endometrial concentrations," The American Journal of Veterinary Research, 46, 1268-1271.

[15] Jones, F.T. and Ricke, S.C. 2003, Observations on the history of the development of antimicrobials and their use in poultry feeds. Poul try Science, 82, 613-617. http://dx.doi.org/10.1093/ps/82.4.613.

[16] Kempf, I., Reeve-Johnson, L., Gesbert, F. and Guittet, M. 1997 Efficacy of tilmicosin in the control of experimental mycoplasma gallisepticum infection in chickens, Avian Diseases, 41, 802-807. http://dx.doi.org/10.2307/1592332.

[17] Main, B.W., Means, J.R., Rinkema, L.E., Smith, W.C. and Sarazan R.D. 1996, cardiovascular effects of the macrolide antibiotic tilmicosin, administered alone and in combination with propranolol or dobutamine, in conscious unrestrained dogs. Journal of Veterinary Pharmacology and Therapeutics, 19, 225-232. http://dx.doi.org/10.1111/j.1365-2885.1996.tb00042.x.

[18] McDougald, L.R. and Reid, W.M. 1997, Coccidiosis. In, B.W. Calnek (Eds). Diseases of Poultry. 10th Ed. Iowa State University Press, Ames, 865- 883.
[19] Papich, M.G. and Riviere, J.E. 2001, Chloramphenicol and derivatives, macrolides, lincosamides and miscellaneous antimicrobials. Veterinary Pharmacology and Therapeutics, 8th edn (Iowa State Press, Ames, IA), 880-881.

[20] Prescott, J. F. 2000, Macrolides and pleuromyilins, in Antimicrobial Therapy in Veterinary Medicine, pp. 229-262, Iowa State University Press, Ames, Iowa, USA, 3rd edition.

[21] Scott, P.R., McGowan, M., Sargison, N.D., Penny, C.D. and Lowman, B.G. 1996, Use of Tilmicosin in a Severe Outbreak of Respiratory Disease in Weaned Beef Calves. Australian Veterinary Journal, 73, 62-64. http://dx.doi.org/10.1111/j.17510813.1996.tb09967.x

[22] Shen, J., Li, C., Jiang, H,, Zhang, S., Guo, P., Ding, S. and Li X. 2005, Pharmacokinetics of tilmicosin after oral administration in swine. American Journal of Veterinary Research, 66, 1071-1074. http://dx.doi.org/10.2460/ajvr.2005.66.1071.

[23] Snedecor, G.W. and Cochran, T. 1976, "Statistical Methods" 6 th $e d$ pp. Ames, lowa U.S.A., 502-503.

[24] Soliman, A. M. and Sedek, M. 2016, Pharmacokinetics and Tissue Residues of Tylosin in Broiler Chickens. Pharmacology \& Pharmacy, 7, 36-42. http://dx.doi.org/10.4236/pp.2016.71006.

[25] Taylor, M.A., Catchpole, J., Marshall, J., Marshall, R. N. and Hoeben, D. 2003, Histopathological observations on the activity of diclazuril (Vecoxan) against the endogenous stages of Eimeria crandallis in sheep. Veterinary Parasitology, 116, 305-314. http://dx.doi.org/10.1016/S0304-4017(03)00256-5.

[26] Vertommen, M. H., Peek, H. W. and Laan, A. 1990, Efficacy of toltrazuril in broilers and development of a laboratory model for sensitivity testing of Eimeria field isolates. Veterinary Quarterly, 12, 183-192. http://dx.doi.org/10.1080/01652176.1990.9694264.

[27] Yamaoka, K., Nakagawa, T. and Uno, T. 1978, Statistical moment in pharmacokinetics. Journal of Pharmacokinetic and Biopharmaceutics, 6, 547-558. http://dx.doi.org/10.1007/BF01062109. 